\title{
Acute intestinal obstruction secondary to left paraduodenal hernia: a case report
}

\author{
Merve Busra Cengiz, M.D., Mustafa Hasbahceci, M.D., Gokhan Cipe, M.D., \\ Oguzhan Karatepe, M.D., Mahmut Muslumanoglu M.D.
}

Department of General Surgery, Bezmialem Vakif University Faculty of Medicine, Istanbul

\begin{abstract}
Paraduodenal hernia, the most common type of internal herniation, is rare in the etiology of intestinal obstruction. Delayed diagnosis and surgical intervention may result in significant morbidity and mortality risk. This report presents a case of left paraduodenal hernia resulting in acute intestinal obstruction. A 43-year old male patient was admitted with a diagnosis of acute intestinal obstruction. A left paraduodenal hernia was identified by computed tomography findings of an encapsulated cluster of dilated small bowel loops occupying the left upper quadrant between the stomach and pancreas, and the presence of an engorged and displaced vascular pedicle at the orifice of the hernia. Upon further investigation, the dilated proximal jejunal segments were found in the left paraduodenal fossa, enclosed in a hernia sac. After reducing the intestinal segments to the abdominal cavity, the orifice of the hernia sac was closed by suturing to the retroperitoneum. Paraduodenal hernia should be considered as a possible etiology in cases of acute intestinal obstruction with unremarkable presentations. Physicians should be familiar with the demonstrative imaging findings of computed tomography of a paraduodenal hernia. Early surgical intervention is critical to prevent the significant morbidity and mortality associated with this condition.
\end{abstract}

Key words: Internal hernia; intestinal obstruction; paraduodenal hernia.

\section{INTRODUCTION}

Small bowel obstruction may be caused by internal herniation, or a protrusion of a viscus through a normal or abnormal peritoneal or mesenteric aperture within the confines of the peritoneal cavity. Internal herniation may be acquired or congenital. ${ }^{[1,2]}$ Internal herniations are classified according to their location, and paraduodenal hernias are the most common type. ${ }^{[1]}$ Although the reported incidence of internal hernia is less than 1\%, internal hernia may account for the underlying pathology in up to $5 \%$ of cases of acute intestinal obstruction. In cases where diagnosis is delayed, intestinal strangulation and gangrene develop and result in a mortality rate of greater than $50 \%{ }^{[1,3]}$

Address for correspondence: Mustafa Hasbahceci, M.D.

Hırkai Şerif Mahallesi, Keçeci Çeşmesi Sokak, Doktorlar Sitesi, B Blok, No: 6/7, Fatih, İstanbul, Turkey

Tel: +90 212 - 6219499 E-mail: hasbahceci@yahoo.com

Qucik Response Code

Ulus Travma Acil Cerr Derg

20I3;19(6):573-575

doi: $10.5505 /$ tjtes.2013.30776

Copyright 2013

TJTES
Widespread use of computed tomography (CT) in acute intestinal obstruction may aid physicians in diagnosing internal herniation through demonstrative preoperative imaging. ${ }^{[2,3]}$ Prompt surgical intervention is essential to reduce the morbidity and mortality associated with internal herniation.

In this paper, we aim to present a case of left paraduodenal hernia causing an acute intestinal obstruction, with particular regard to the associated imaging findings.

\section{CASE REPORT}

A 43-year old male patient was admitted to our emergency department with abdominal pain, distention, nausea, vomiting, and obstipation for one day. The patient history revealed no systemic disease. He had previously undergone appendectomy and laparoscopic cholecystectomy. All vital signs were stable. Physical examination revealed marked abdominal distension, rebound tenderness, and abdominal guarding, especially in the left upper quadrant. Multiple air-fluid levels were observed on the abdominal X-ray. Laboratory analyses including complete blood count and biochemical analysis of the biliary and urinary systems were all normal except for an elevated leukocyte count of $14.000^{3} / \mu \mathrm{L}$. An abdominal CT scan demonstrated an encapsulated cluster of dilated small bowel loops primarily occupying the left upper quadrant between 


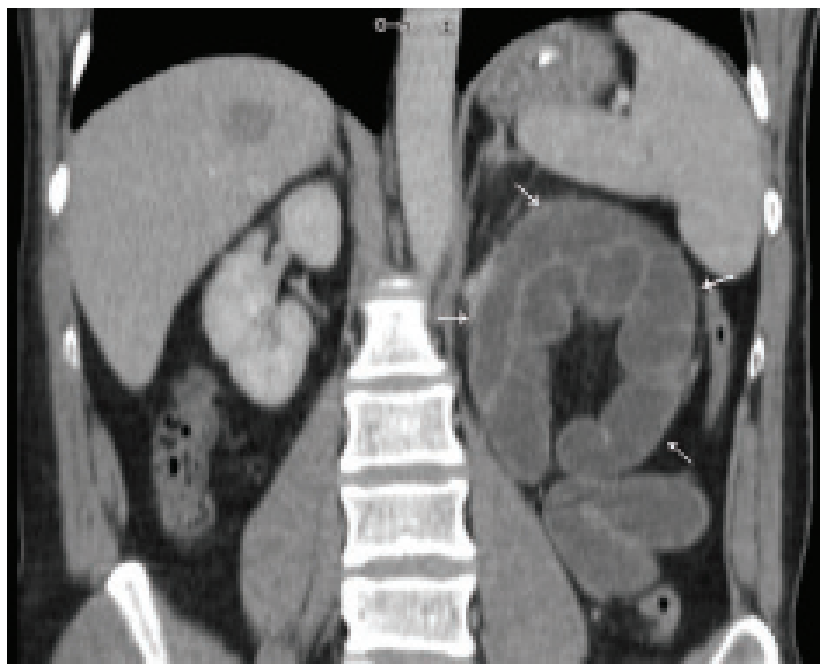

Figure 1. A coronal CT scan showing an encapsulated (between arrows) cluster of dilated small bowel loops occupying the left upper quadrant.

the stomach and the pancreas (Figure I), and the presence of an engorged and displaced vascular pedicle at the orifice of the hernia (Figure 2). The patient underwent emergent laparotomy with a diagnosis of left paraduodenal hernia. On surgical exploration, the dilated proximal jejunal segments were found in the left paraduodenal fossa, which was enclosed in a hernia sac. After reducing the intestinal segments to the abdominal cavity, the orifice of the hernia sac was closed by suturing the retroperitomeum. The patient was discharged following an uneventful recovery.

\section{DISCUSSION}

Internal hernia, which may be either acquired or congenital, is the protrusion of a viscus through a normal or abnormal peritoneal or mesenteric aperture within the confines of the peritoneal cavity. ${ }^{[l]}$ The orifice of the hernia is either a preexisting anatomic structure, such as the foramen of Winslow, or a pathologic defect caused by a congenital or acquired etiology. ${ }^{[2,3]}$

There are several distinct types on internal herniation with varying prevalence: left or right paraduodenal (53\%), pericecal (13\%), foramen of Winslow (8\%), trans-mesenteric and trans-mesocolic (8\%), intersigmoid (6\%), and retroanastomotic (5\%). Among these, paraduodenal hernia is the most common pathology. While paraduodenal hernias are 3 times more common in men, other types of internal herniation. ${ }^{[l]}$ Although this type of hernia is congenital, presentation usually occurs in the 4th through 6th decades of life, as in this case. ${ }^{[4,5]}$ Demographic features of the case presented in this study are consistent with the known risk factors for internal hernia. Despite past history of previous surgeries, these interventions are unlikely to be significant in the etiology of left paraduodenal hernia. However, it is important to note that the incidence of trans-mesenteric or trans-mesocolic hernia

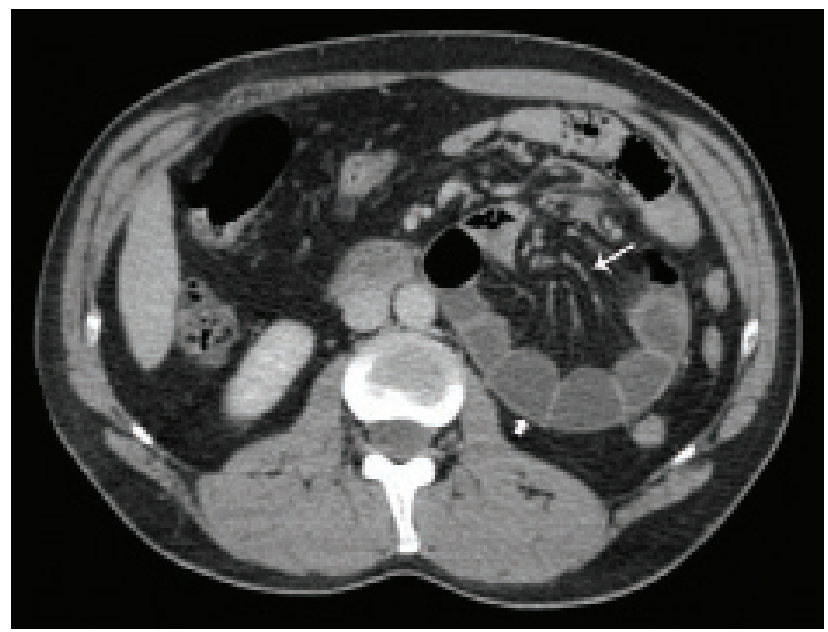

Figure 2. An axial CT scan showing engorged and displaced vascular pedicle (thin arrow) at the orifice of the hernia, and dilated small bowel loops around this vascular pedicle in a hernia sac (thick arrow).

derived from the use of novel surgical procedures has increased in recent years and differential diagnosis should take this into consideration. ${ }^{[l]}$

Paraduodenal hernias are classified in two categories according to their left or right side localization. Left paraduodenal hernia is defined as the herniation of the bowel through Landzert's fossa, an aperture found in approximately $2 \%$ of the population. ${ }^{[3]}$ Left sided paraduodenal hernia is more common than right-sided hernia, accounting for approximately $40-50 \%$ of all internal hernias. Landzert's fossa is a hole through the mesocolon of the transverse colon located behind the ascending or fourth segment of the duodenum formed by the lifting of the peritoneal fold by the inferior mesenteric vein and ascending left colic artery running along the lateral fossa. ${ }^{[1,6]}$

The most common presentation of internal herniation is acute small bowel obstruction with pain on the left upper segment of the abdomen, distention, nausea, vomiting, and obstipation. Some patients may experience recurrent symptomatic episodes that are often postprandial and relieved in the supine position. ${ }^{[7]}$ Diagnosis of paraduodenal hernia is often difficult due to variable presentation and unremarkable findings during the physical examination. However, paraduodenal hernia should be considered in cases of acute intestinal obstruction in male patients with no prior history of abdominal surgery.

Radiological imaging systems are essential for early diagnosis and facilitate planning of surgical treatment. Intestinal obstruction is typically diagnosed by abdominal $\mathrm{X}$-ray. ${ }^{[8]} \mathrm{How}-$ ever, CT is emerging as the most effective method for the diagnosis of paraduodenal hernia. ${ }^{[6]}$ Encapsulated clustering of bowel loops at the duodenojejunal junction between the stomach and the pancreas to the left of the ligament of Treitz 
or behind the pancreatic tail itself and the left displacement of the inferior mesenteric vein are the major descriptive imaging features. Depression of duodenojejunal junction causing dilatation and air-fluid levels in the trapped loops, and the engorgement and crowding of the mesenteric vessels are characteristic features. Preoperative diagnosis of paraduodenal hernia was possible in this case as a result of several published reports describing diagnostic imaging characteristics. ${ }^{[2,7]}$

Surgical treatment of left paraduodenal hernia follows the basic principles of hernia surgery: reduction of the contents, restoration of normal anatomy, and repair of the defect. ${ }^{[7]}$ However, prompt surgical intervention is required for the prevention of strangulation and gangrene in cases with acute intestinal obstruction. After removal of the contents of the hernia sac, the viability of the bowel should be determined. During closure of the defect with non-absorbable sutures, attention should be given to avoid injury to the inferior mesenteric vein, located just anterior and lateral within the orifice. In cases where a defect prevents repair using sutures, widening of the defect may be performed to avoid future herniation. ${ }^{[5]}$

In conclusion, internal herniation, and specifically paraduodenal hernia, is an unusual cause of acute intestinal obstruction. Internal herniation should be considered as the possible etiology of acute intestinal obstruction due to the unremarkable and nonspecific presentation. CT is a valuable imaging technique for patients with acute abdominal pain. Physicians should be familiar with the characteristic imaging findings for internal herniation. Early surgical intervention is critical to avoid the morbidity and the mortality associated with this condition.

\section{Conflict of interest: None declared.}

\section{REFERENCES}

1. Martin LC, Merkle EM, Thompson WM. Review of internal hernias: radiographic and clinical findings. AJR Am J Roentgenol 2006;186:70317. [CrossRef]

2. Selçuk D, Kantarci F, Oğüt G, Korman U. Radiological evaluation of internal abdominal hernias. Turk J Gastroenterol 2005;16:57-64.

3. Fernández-Rey CL, Martínez-Álvarez C, Concejo-Cutoli P. Acute abdomen secondary to left paraduodenal hernia: diagnostic by multislice computer tomography. Rev Esp Enferm Dig 2011;103:38-9. [CrossRef]

4. Bittner JG 4th, Edwards MA, Harrison SJ, Li K, Karmin PN, Mellinger JD. Laparoscopic repair of a right paraduodenal hernia. JSLS 2009;13:242-9.

5. Huang YM, Chou AS, Wu YK, Wu CC, Lee MC, Chen HT, et al. Left paraduodenal hernia presenting as recurrent small bowel obstruction. World J Gastroenterol 2005;11:6557-9.

6. Al-Khyatt W, Aggarwal S, Birchall J, Rowlands TE. Acute intestinal obstruction secondary to left paraduodenal hernia: a case report and literature review. World J Emerg Surg 2013;8:5. [CrossRef]

7. Yun MY, Choi YM, Choi SK, Kim SJ, Ahn SI, Kim KR. Left paraduodenal hernia presenting with atypical symptoms. Yonsei Med J 2010;51:787-9. [CrossRef]

8. Sen M, Inan A, Dener C, Bozer M. Paraduodenal internal hernias: clinical analysis of two cases. Ulus Travma Acil Cerrahi Derg 2007;13:232-6.

\section{OLGU SUNUMU - ÖZET}

\section{Sol paraduodenal fıtığa bağlı akut intestinal tıkanıklık: Olgu sunumu \\ Dr. Merve Busra Cengiz, Dr. Mustafa Hasbahceci, Dr. Gokhan Cipe, Dr. Oguzhan Karatepe, Dr. Mahmut Muslumanoglu \\ Bezmialem Vakıf Üniversitesi Tıp Fakültesi, Genel Cerrahi Anabilim Dalı, İstanbul}

Paraduodenal fıtık, internal fıtığın en sık görülen tipi olarak akut intestinal tıkanıklığın nadir bir sebebidir. Tanı ve cerrahi tedavideki gecikmeler yüksek morbidite ve mortalite için önemli olabilir. Bu yazıda, akut intestinal tıkanıklığa sebep olan bir sol paraduodenal fıtık olgusu sunuldu. Kırk üç yaşındaki bir erkek hasta akut intestinal tıkanıklık ön tanısı ile başvurdu. Bilgisayarlı tomografide saptanan, mide ile pankreas arasında özellikle sol üst kadranı dolduran enkapsüle dilate ince bağırsak segmentleri kümesi ve fitık açıklığında bulunan genişlemiş ve yer değiştirmiş ince bağırsak vasküler pedikülü bulguları ile sol paraduodenal herni tanısı kondu. Eksplorasyonda, sol paraduodenal fossa yerleşimli bir fıtık kesesi içerisinde sınırlanmış dilate proksimal ince bağırsak segmentlerinin olduğu görüldü. Bağırsak segmentleri karın içi boşluğa redükte edildikten sonra, fıtık açıklığı retroperitona dikilerek kapatıldı. Paraduodenal fıtık, belirgin olmayan başvuru şekli nedeniyle akut intestinal tıkanıklığın olası bir sebebi olarak düşünülmelidir. Hekimler bilgisayarlı tomografi ile elde edilebilen tanısal görüntüleme bulgularına aşina olmalıdır. Erken cerrahi girişim, bu hastalık ile ilişkili morbidite ve mortalitenin azaltılması için önemlidir.

Anahtar sözcükler: Internal fıtık; intestinal tıkanıklık; paraduodenal fıtık.

Ulus Travma Acil Cerr Derg 2013;19(6):573-575 doi: 10.5505/tjtes.20I3.30776 